\title{
口腔咽頭食道領域に多中心性発癌を認めた一症例
}

\author{
渡邊 暢浩・高木 一平・羽柴 基之 \\ 伊藤 博隆・馬場 駿吉
}

\section{A Case of Multicentric Carcinogenesis in Oral Cavity, Pharynx and Esophagus}

Nobuhiro Watanabe, Ippei Takagi, Motoyuki Hashiba, Hirotaka Ito and Shunkichi Baba

(Nagoya City University Medical School)

We report a 48-year-old man with carcinomas in three separate regions of the tongue. During treatment, newly developing carcinomas were found in the hypopharynx and esophagus. In the lower esophagus, field carcinogenesis was observed and was detected by Lugol's solution spraying method under esophagoscopy.

It is well recognized that tabacco and alcohol significantly increase the risk of field carcinogenesis in head and neck cancer. Our case also had a past history of drinking (Sake index: 200). Additionally, the correlation between multiple primary cancer of the head and neck and genetic predisposition such as human leukocyte antigen (HLA) has been clarified. The types of HLA-A9 (24), Aw33, B5, B17, Cw3 and DR2 (w15) were detected in our case.

Currently, the clinician must be attentive to second primary cancer in order to extend the survival of patients.

Key words: head and neck cancer, multicentric carcinogenesis, human leukocyte antigens, Lugol's solution spraying method

\section{緒 言}

頭頸部領域で多中心性に発癌を認めたとする 症例報告は多いが1) 6), 頻度としては頭頸部癌 の 5 ４5\%の範囲の報告がなされている7) 11). 多くは 2 部位に発癌を認めた症例であり, なか でも中咽頭あるいは下咽頭と頸部食道の組み合 わせの頻度が高い。これら上気道, 上部消化管 に抢ける発癌には環境因子の影響が大きいこと が，諸家により報告されているが，最近では免 疫, 遺伝学的背景のひとつとして Human
Leukocyte Antigen (HLA) との関連も示唆され ている12).

今回我々は，同時期発生したと考えられる多 中心性の舌扁平上皮癌に引きつづき，下咽頭・ 食道にも扁平上皮癌の発生を認めた稀な多発癌 症例を経験したので，その概要を報告すると共 に, 若干の文献的考察を加えた.

症例

48歳 男性.

主訴: 舌痛. 
現病歴: 昭和63年 3 月頃, 舌左縁部の粗䊁感 を伴った腫瘍に気付くも疼痛がないため放置し ていた. 同年 4 月頃より, 摂食時に舌痛が出現 し，徐々に摂食困難となってきたため，5月 2 日近医受診したが軽快せず， 6 月 1 日当科紹介 され受診した。

既往歴 : 26 歳; 肺結核, 入院治療. 44歳; アルュール性肝炎, 通院治療.

家族歷：特記すべき事項なし.

飲酒歴 : ビール10本/日 20 年.

(Sake index:200)

契煙歴：なし.

入院時所見: 全身的所見は, 体格中等度瘦せ 型であるほか，特記すべき所見はなかった。口 腔内所見は図 1 のごとく, 舌左縁舌根部付近に， 中心に潰瘍を伴った約 $3 \mathrm{~cm}$ の硬結を触れ，同 側舌尖に近い部位の, 舌口腔底粘膜移行部に 1 $\mathrm{cm}$ に満たない腫瘍を認めた. 舌右縁舌根部に は, 長径 $1 \mathrm{~cm}$ 程の発赤腫脹を認めた. これら 3 病変は, 視診触診等で連続性が認められなか
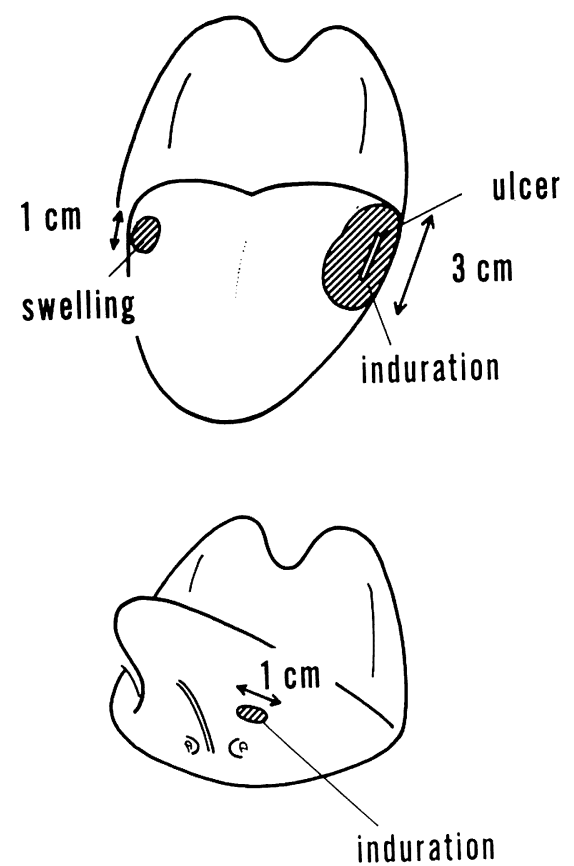

図 1 初診時における舌腫瘍の部位と大きさ
つた。 また舌の知覚障害, 運動制限は特に認め られず，言語，咀嚼障害も明らかなものはなか った.

体表リンパ節は, 顎下部, 頋部, 頸部をはじ めとして触知されなかった。

臨床検査所見も，軽度低色素性正球性貧血を 認める注か, 特記すべき異常はなく, 胸部単純 X線写真上，異常陰影を認めなかった。

診断扣よび治療経過：臨床的に舌癌と診断し， 上記硬結・潰瘍から生検を行なったところ，3 力所とも高分化扁平上皮癌との病理組織診断を 得た. $\mathrm{Ga}$ シンチグラム, 骨シンチグラム上, 他の部位には異常集積を認めず, $\mathrm{T}_{2} \mathrm{~N}_{0} \mathrm{M}_{0}$, stage II とした. シスプラチン+ペプロマイシンにて 両側浅側頭動脈より動注療法を開始し，2 クー ル施行後，局所にリニアック $30 \mathrm{~Gy}$ を照射した. 腫瘍サイズの縮小が認められたが，完全消失に は至らず, 昭和 63 年 9 月 8 日舌喉頭全摘術, 左 頸部郭清術, 大胸筋皮弁による再建術を行なっ た. 検索し得たすべてのリンパ筋に転移はなく， 摘出組織の境界部でも, 組織学的に腫瘍は認め られなかった. 術後約 3 カ月に, 下咽頭後壁に 径数 $\mathrm{mm}$ の小腫瘍が認められ, 病理組織学的 に中分化扁平上皮癌との診断を得たため, メト トレキサート十ビンデシンによる化学療法を 2 クール施行後, 平成元年 1 月 26 日下咽頭腫瘍摘 出術を行なった。術後, さらに局所に $54 \mathrm{~Gy}$ 照 射し，4月初め退院した。

外来経過観察中 6 月に入って, 左口蓋扁桃下 極よりやや下の部位に, 小腫瘍が発見され生検 で扁平上皮癌との病理組織学的診断を得たため, 入院し6月19日同部位腫瘍摘出術を施行したの ち, Cryosurgery とェトポシド(経ロ), テガ フール（坐剤）の併用療法を行なった.

食道内視鏡検査では，前回入院時には，下部 食道の食道炎および一部に軽度 dysplasia を認 めると診断されていたが，平成元年 8 年10日， ルゴール液を用いた色素食道内視鏡検査を施行 し，上門歯列より $28 \mathrm{~cm}$ 及び $30 \mathrm{~cm}$ に図 2 の ようにルゴール不染域が斑状にみられたため, 
同部位より生検した。その結果，扁平上皮癌と の組織診断を得たため, リニアック $50 \mathrm{~Gy}$ 施行 し，以後ブレオマイシン十ポリアクリル酸ナト リウム（パナカヤク）の内服にて経過観察して いる。
病理組織学的所見：図 3 の如く舌及び右口蓋 扁桃下極部の癌は角化傾向の強い高分化型扁平 上皮癌と, 下咽頭・食道癌は角化傾向の乏しい 中分化型扁平上皮癌と診断された。

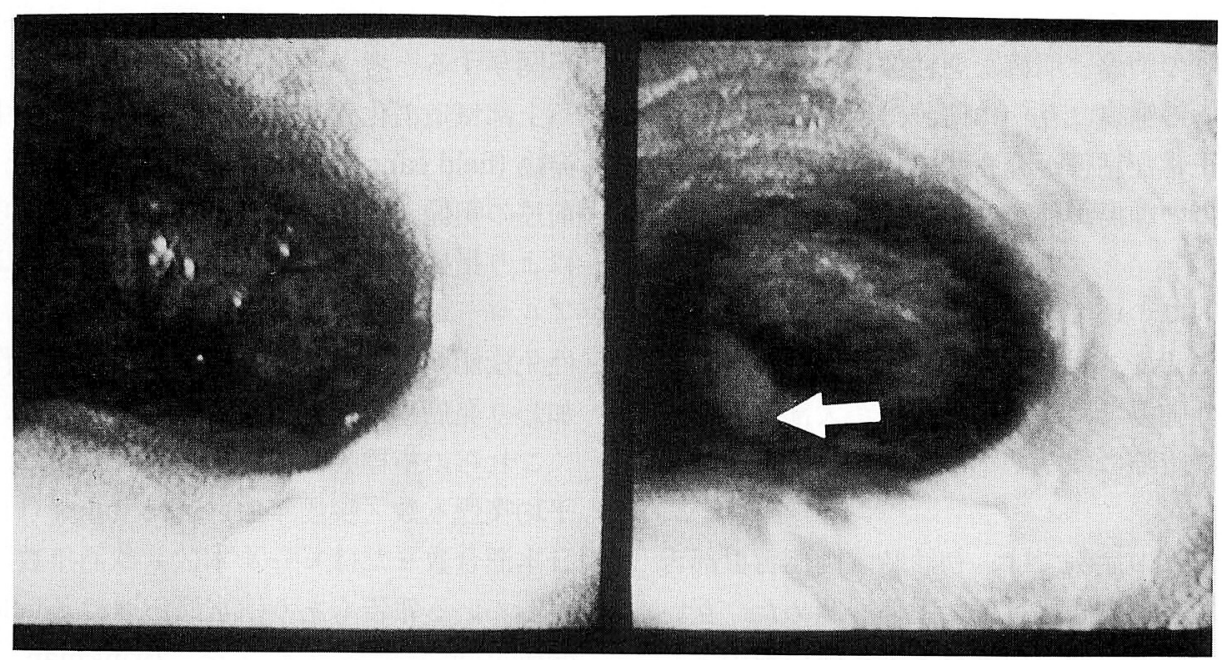

$\mathrm{a} ：$ ル゙ール塗布前

b : ルゴール塗布後

図 2 食道内視鏡所見

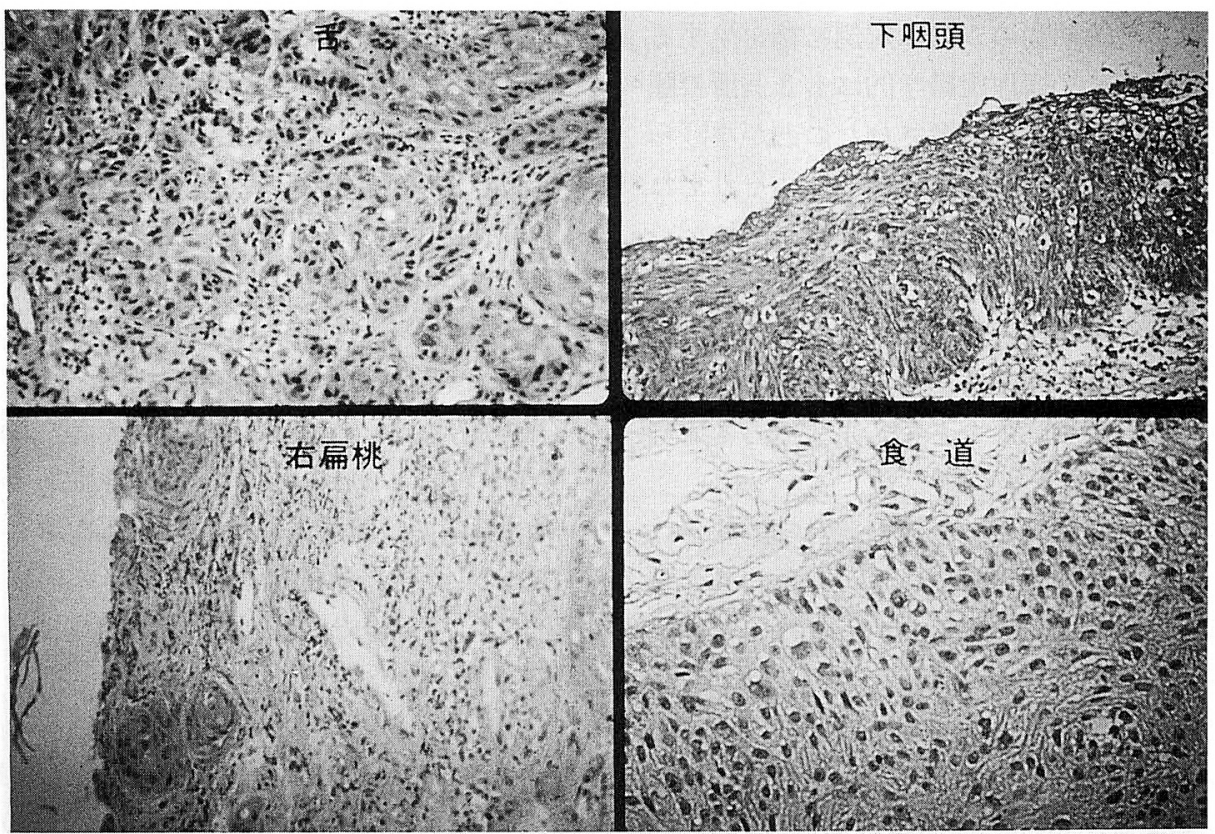

図 3 病理組織像 


\section{考察}

1 個体に同時に 2 個以上の原発性癌を認める 多発癌は, Billroth ${ }^{13)}(1889)$ により報告されて 以来, 数多くの報告々議論の集積がある. 最近 では，1932年に Warren \& Gates ${ }^{14)}$ により提唱 された以下の基準が一般には用いられている。

(1)各々の腫瘍は明確な悪性像を呈する

(2)各々の腫瘍は互いに離れた部位にあり，明 らかに正常な粘膜が介在する

(3)一方の腫瘍が他方の転移であることが除外 される.

但し, (3)については，十分条件として組織型が 異なることを挙げている者もいる4). しかし頭 頸部悪性腫瘍では, 扁平上皮癌が大部分を占め ており，実際には基準(3)につては立証不能な 例も多い.

われわれの症例では, 初診時, 両側舌根部舌 縁及び左舌口腔底移行部に腫瘍を認めた。互い に一方の腫瘍が他方の転移と考え難い理由とし て(1)舌に拈いては舌中隔が腫瘍の進展転移に対 する barrier としてはたらいている可能性が高 (5). (2)所属リンパ節転移が認められないにも かかわらず，短期間のらちに対側転移を生ずる 可能性は低い. (3)病理組織学的にも3 個所の腫 瘍の連続性がそれぞれ否定されたことが挙げら れる。したがって，これら 3 病変は，それぞれ 独立した原発性癌と考えてょいと思われた.

Fitzpatrick ら9) によれば，口腔内扁平上皮癌 2891 症例のうち 3 個所に多発したのは55例であ り, このなかには多臓器にまたがるもの, 異時 発生のものも含まれることを考虑すると本症例 はかなり稀と考えられた。

口腔咽頭食道領域の多発癌の統計学的報告は 諸家1718226)によりなされている.われわれの掌 握し得た限りでは, Gluckman ら ${ }^{15)}$ は, 口腔・ 咽頭癌のうち多発癌の頻度を $15.4 \%$, Kotwall ら ${ }^{11)}$ は20.2\%とし，また仲ら ${ }^{6)}$ は下咽頭癌に拈 ける多発癌の頻度として16.7\%を挙げている. 下咽頭・食道に打ける多発癌の頻度は馬谷ら1) によれば10.8\%，多幾山ら 2 は は $57 \%$ と報告して
いる，母集団の大ささにもよるが，看過できな い頻度と考兄られた。これは，口腔から下咽頭 を経て食道までは重層扁平上皮が覆って括り， 解剖学的にも組織学的にもそれぞれの境界は不 明瞭であるらえに，妿煙・アルコール多飲とい った慢性的な刺激に一様に暴露されやすいこと が関与すると考兄られる.

上部気道消化管に括ける発癌, 特に多中心性 発癌 (field cancerization) の risk factor として, 前述の契煙とアルコール多飲は，以前から諸家 により指摘されて扣り22223)，宮原ら 16$)$ にれば， アルコール多飲による慢性的な粘膜刺激, 細胞 性免疫能の低下, これに妿煙の相加相乗作用が 加わり発癌に大きく関与しているといら.

これらの指標として, Brinkman index (1日 平均喫煙本数 $\times$ 契煙年数) Sake index (1日平均 日本酒合数またはビール本数 $\times$ 飲酒年数) を検 討している報告もあり，宮原ら ${ }^{16)}$ は, field cancerizationの危険ラインを, Brinkman index 600かつまたは Sake index 30としている. 仲 ら6)によれば，下咽頭癌の多発例と非多発例と の間でこれらの指標に有意差を認め, 多発例の 平均 Brinkman index は1560, 平均 Sake index は141であったとし，われわれの症例でも契煙 歴はないものの, Sake index は200と高值を示 し, アルコール多飲との関連が示唆された.

しかしながら一方では，契煙歴・飲酒歴のな い症例があることから, 遺伝的素因の関与も指 摘されている。近年 Human Leukocyte Antigen (以下 HLA) が, 疾患の原因・診断・予後 との関連に括いて注目されているが, Nico de Vries ら ${ }^{12)}$ によれば, 頭頸部悪性腫瘍多発癌症 例に打いては健康人に比して HLA B8, DR3, DQw2 が統計学的に有意に高率に認められた といら。われわれの症例では, A9 (24), Aw33， B5, B17, Cw3, DR2 (w15)を保持していたが, このうち A9, B5, Cw3 については日本人に多 い27)とされているものであった. HLA-B17 に ついては，Chan らの報告28)にあるように中国 人上咽頭癌患者に有意に高頻度で認められるも 
ので，日本人ではごく稀である，いずれにせよ 本症例 1 例のみで判断できるものではないので, 今後の多数の症例の集積を持って検討する必要 がある。

頭頸部悪性腫瘍, 殊に中・下咽頭癌の診断に あたっては重複・多発癌が多く，第二原発部位 としては, 前述のような口腔咽頭食道領域ばか りでなく肺にも認められ，Kotwall らは，第二 原発部位を頭頸部・肺・食道の 3 個所に分類し た際, 肺の占める割合は食道の割合より高く $31.6 \%$ と報告している，したがって，原発巣に とどまらず，肺・食道の精查は必要不可欠であ り, 具体的には上部消化管, 下気道の観察を 含めた, panendoscopy が重複多発癌のスク リーニング検査として有用であるとの報告もあ る19200．本症例では，バリウムを用いた食道透 視および食道内視鏡検査を繰り返し施行するも 明らかな異常が認められなかった。しかしル ゴール染色法24)25)により不染域が食道のほぼ全 域にわたってみられ，これらの部位からの生検 で扁平上皮癌の存在が指摘された。したがって， panendoscopy にとどまらず色素内視鏡検査を 組み入れることにより，下咽頭・食道の重複・ 多発癌の早期診断が可能となるといえる.

頭頸部多発癌の治療は, field cancerization ${ }^{8)}$ も考慮し, 手術的に各原発部位を十分な範囲で 切除すること, 特に近接して複数の腫瘍が存在 する場合は, en bloc 切除が望ましい, 手術療 法に加えて化学療法, 放射線療法等を組又合わ せる集学的治療が重視されるのは, 他の単発性 癌と同様である. しかしながら，壁内転移に比 し多発癌の予後は良好であること, 多発性であ ればあるほど手術侵襲も大きくなることから， 症例によっては quality of life を重視した治療 法の選択も必要となる. 本症例では, 舌全摘, 喉頭全摘後に発見された食道多発癌に対しては, 放射線療法の後, 保存的にブレオマイシンーポ リアクリル酸ナトリウム（パナカヤク）の内服 による局所化学療法を周期的に繰り返した結果, 現在までのところ腫瘍の増大進展傾向は認めら
れていない。

頭頸部重複癌・多発癌の治療の難しさは, 単 一癌との予後に拈ける差となって現われている. この理由として，(1)もともと原発部位としての 予後の悪い食道・肺に，第二原発癌が見出され る頻度が高いこと，(2)第二原発癌の発見が遅れ， 既にかなり進行していることが多いこと，(3)多 発癌に対する効果的な治療体系ができていない こと，がある．しかし多発癌といえども，同時 期発癌と異時発癌においては, 前者の方が予後 が良いとの統計15) があるので，第一原発癌 (index tumor) が発見された時点で第二原発癌を 見逃すことなく，早期発見の為に努力を惜しま ぬことが重要である.

\section{結語}

1. 口腔咽頭食道領域に, 多中心性発癌を認 めた 1 症例を報告した.

2. 口腔咽頭食道領域の多発性癌には, 契煙 ・アルコール多飲が大きく関与しており，これ らの指標として Brinkman index, Sake index は参考となると考兄られた．本症例でもかなり の飲酒歴を認め, Sake indexは200であった。

3. 本症例のよらな多発食道癌の早期発見に, 色素内視鏡検査は非常に有用であった.

4. 現在のところ頭頸部癌症例において, 第 二原発癌の早期発見が最重要である.

5 . 頭頸部領域多発性癌の早期診断・予後と の関連において, HLA の検索が今後重視され るようになると考えられるが，多くの症例の集 積と検討が必要である。

6. 本症例では, 多発食道癌に対し局所化学 療法を試みているが，今後，頭頸部多発癌症例 の治療方針決定の上で quality of life は無視で きないと考えられた。

\section{参考文献}

1）馬谷克則, 鶴田至宏, 吉野邦俊, 他：下咽頭 頸部食道がんに拈ける多中心性発がん。耳鼻臨 床 $78: 73 \sim 85,1985$.

2）多幾山渉, 山口佳之, 佐伯俊昭, 他: 下咽頭 · 頸部食道がんに扣ける食道内がん多発をみた 4 
症例の検討. 癌の臨床 $32: 392 \sim 400,1986$.

3) Hong WK : Multiple primary squamous cell carcinoma of head and neck. Am J Clin Oncol $10: 2 ; 182 \sim 183,1987$.

4）斉藤 弘, 田川俊郎, 宮原慎児, 他：口腔内に みられた原発性多発癌の 1 症例. 日本口腔外科 学会雑誌 $31: 4 ; 750 \sim 753,1985$.

5）小谷順一郎, 中田茂樹, 西 正寛, 他 : 両側舌 縁部に対称的に出現した多発性癌の 1 例. 日本 口腔外科学会雑誌 $25: 3 ; 168 \sim 172,1979$.

6）仲 博美, 真栄田宗慶, 広田敦子, 他 : 下咽頭 重複癌, 多発癌と上部消化管内視鏡検査. 日気 食会報 $41: 1 ； 1 \sim 6,1990$.

7) Shibuya H, Hisamitsu S, Shioiri S, et al : Multiple primary cancer risk in patients with squamous cell carcinoma of the oral cavity. Cancer 60 : 3083 3086, 1987.

8) Slaughter DP, Southwick HW and Smejkal W :

"Field cancerization" in oral stratified squamous epitherium. Cancer $6: 963 \sim 968$, 1953.

9) Fitzpatrick PJ, Tepperman BS and deBoer G : Multiple primary squamous cell carcinomas in the upper digestive tract. Int J Radiat Oncol Biol Phys 10 : 2273 2279, 1984.

10) Miyahara $H$, Tsuruta $Y$, Umatani $K$, et al : Multiple primary tumors in patients with head and neck cancer. Auris Nasus Larynx 12 Suppl $2: 30 \sim 35,1985$.

11) Kotwall C, Razack MS, Sako K, et al : Multiple primary cancers in squamous cell cancer of the head and neck. J Surg Oncol $40: 97 \sim 99$, 1989.

12) de Vries N, Drexhage HA, de Waal LP, et al : Human leukocyte antigens and immunoglobulin allotypes in head and neck cancer patients with and without multiple primary tumors. Cancer 60 : 957 961, 1987.

13) Billroth $T:$ Die Allgemeine Chirurgische Pathologie Und Therapeutie. ed 14. p 908, Berlin G Reimer, 1889.

14) )Warren $S$ and Gates $O$ : Multiple primary malignant tumors; a survey of the literature and a statistical study. Am J Cancer 16:1358 $\sim 1414,1932$.

15) Gluckman JL and Crissman JD : Survival rates in 548 patients with multiple neoplasms of the upper aerodigestive tract. Laryngoscope 93 : $71 \sim 74,1983$.

16）宮原 裕, 佐藤武男 : 頭頸部悪性腫瘍の発癌要 因 (第 2 報)一アルュール症症例の検討一. 日 耳鼻 $84: 146 \sim 153,1981$.

17）川本誠一, 池田 恢, 西山諾司, 他 : 頭頸部癌 症例に括ける重複癌一重複部位・頻度など統計 的考察一. 癌の臨床 $28: 1 \sim 7,1982$.

18) Schoenberg BS and Myers $\mathrm{MH}$ : Statistical methods for studying multiple primary malignant neoplasms. Cancer $40: 1892 \sim 1898,1977$.

19) McGuirt WF, Mathews $B$ and Koufman JA : Multiple simultaneous tumors in patients with head and neck cancer; a prospective sequential panendoscopic study. Cancer $50: 1195 \sim 1199$, 1982.

20) McGuirt WF : Panendoscopy as a screening examination of simultaneous primary tumors in head and neck cancer; a prospective sequential study and review of the literature. Laryngoscope $92:$ 569 576, 1982.

21) Licciardello JTW, Spitz MR and Hong WK : Multiple primary cancer in patients with cancer of the head and neck, esophagus and lung. Int J Radiat Oncol Biol Phys 17 : 467 476, 1989.

22) Moore $C$ : Cigarette smoking and cancer of the mouth, pharynx and larynx. JAMA $218: 4$; 553 558, 1971.

23) Wynder EL, Mushinski MH and Spivak JC : Tabacco and alcohol consumption in relation to the development multiple primary cancers. Cancer $40:$ 1872 1878, 1977.

24）佐野元哉, 奥田 茂, 谷口春生, 他: 食道癌内 視鏡診断一ルゴール法の応用について一. 外科 Mook 24. 25 36頁, 金原出版, 東京, 1982.

25）吉井由利, 中村常哉: ルゴール染色法による食 道癌の早期発見. 現代医学 $38: 3 ; 539 \sim 543$, 1991.

26) Shara AR, Hoover EL, Mitrani M, et al : Synchronicity, multicentricity and metachronicity 
of head and neck cancer. Head Neck Surg $10: 4 ; 225 \sim 228,1988$.

27）佃守，持松いら゙み，矢野間俊介，他：日本 人上咽頭癌症例の HLA 抗原. 医学のあゆみ $129: 10 ; 703 \sim 706,1984$.

28) Chan SH, Day NE, Kunaratram N, et al : HLA and nasopharyngeal carcinoma in Chinese; a further study. Int J Cancer 32 : 171 176, 1983.

$\left(\begin{array}{l}\text { 別刷請求先 : 渡邊暢浩 } \\ \text { T467 名古屋市瑞穂区瑞穂町川澄 } 1 \\ \text { 名古屋市立大学医学部耳鼻咽喉科学教室 }\end{array}\right)$ 